\title{
Pemberdayaan Masyarakat Sekitar TPA (Tempat Pembuangan Akhir) Dalam Pemanfaatan Sampah Non Organik Menjadi Kerajinan Untuk Meningkatkan Nilai Jual
}

\author{
Moh. Mahmud', Sugiyono², Sumari Mawardi ${ }^{3}$, Munawir $^{4}$ \\ IAI Darussalam Blokagung Banyuwangi \\ Email : ${ }^{1}$ mohmahmud060578@gmail.com
}

\begin{abstract}
This paper provides an overview of the condition of the community around the TPA (Final Waste Disposal Site) of Sumberejo hamlet Wringinagung Village Gambiran District Banyuwangi Regency in processing non-organic waste into handicrafts that have more selling value to improve the community's economic level. The community service approach used is PAR (Participatory Action Research) in the form of community training and training. The results of this dedication show the enthusiasm of the community to be able to participate in these activities and practice them in order to get more economic resources and meet their daily needs
\end{abstract}

Keywords: Non-organic waste processing, handicrafts, community economic level

\section{Pendahuluan}

Pelatihan mengenai pembuatan kerajinan tangan dari sampah non organik bagi masyarakat sekitar TPA sangat urgen dilakukan untuk memberikan nilai manfaat bagi mereka yang berpeluang untuk meningkatkan taraf ekonomi melaui pemanfaatan sampah non organik yang ada didekat tempat tinggal mereka ${ }^{1}$.

Desa Wringinagung sebagai wilayah pengabdian Pengabdian Kepada Masyarakat (PKM) IAIDA merupakan salah satu dari 6 desa yang berada di wilayah kecamatan Gambiran kabupaten Banyuwangi. Luas wilayah Desa

${ }^{1}$ Ardiansyah, Tomi. Sampah Anorganik Dan Pemanfaatannya. https://foresteract.com/sampah-anorganik-dan-pemanfaatannya/diakses: $\quad 15$ Nopember 2019., 2017

Pemberdayaan Masyarakat Sekitar TPA (Tempat Pembuangan Akhir) Dalam Pemanfaatan Sampah Non Organik Menjadi Kerajinan Untuk Meningkatkan Nilai Jual

Moh. Mahmud, Sugiyono, Sumari Mawardi, Munawir 
Wringinagung menurut penggunaan luas pemukiman adalah 619.9 Ha dan luas sawah 316 Ha yang terbagi menjadi 4 Dusun, yaitu: Dusun Sumberjo, Dusun Sumberjaya, Dusun Jatisari dan Dusun Glowong. Secara administrasi Desa Wringinagung, Kecamatan Gambiran Kabupaten Banyuwangi terdiri dari 46 RT dan 10 RW dengan batas-batas sebelah utara Berbatasan dengan Desa Yosomulyo Kecamatan Gambiran, sebelah selatan berbatasan dengan Desa Purwodadi Kecamatan Gambiran, sebelah timur berbatasan dengan Desa Jajag Kecamatan Gambiran dan sebelah barat berbatasan dengan Desa Tegalsari Kecamatan Gambiran. ${ }^{2}$

Desa Wringinagung Kecamatan Gambiran memiliki jumlah penduduk \pm 7780 jiwa yang terdiri dari 3852 jiwa penduduk laki-laki dan 3928 jiwa perempuan. Potensi Desa Wringinagung cukup besar, dengan potensi yang sudah dimanfaatkan secara maksimal. Potensi yang ada baik sumber daya alam maupun sumber daya manusianya perlu terus digali dan dikembangkan untuk kemakmuran masyarakat secara umum. ${ }^{3}$

Masyarakat merupakan sekelompok individu yang saling berinteraksi antara individu satu dengan individu yang lain, antar kelompok satu dengan kelompok yang lain. Melalui Implikasi dari interaksi tersebut sangat diperlukan terwujidnya komunikasi sosial, yang mana setiap individu akan memiliki variasi pola pikir, visi, serta misi sesuai dengan karakteristik individu masing-masing.

Dalam kehidupan sosial bermasyarakat, perbedaan pandangan dan prinsip adalah hal yang lumrah terjadi, karena setiap individu mempunyai keinginan dan kepentingan yang berbeda. Sehingga dalam berinteraksi mereka memiliki cara yang tidak sama pula. Pada saat cara yang dilakukan

\footnotetext{
${ }^{2}$ Desa Wringinagung, Buku Profil Desa WringinagungTtahun 2016. Desa Wringinagung Kecamatan Gambiran Kabupaten Banyuwangi (2018)

3 ibid
} 
oleh setiap individu itu tidak sepadan dan berbenturan, maka akan menumbuhkan suatu perbedaan. Sehingga dari sini terdapat pentingnya komunikasi sosial tersebut, dalam rangka menyatukan pandangan dan prinsip agar tidak menimbulkan terjadinya konflik dalam lapisan masyarakat. Masyarakat Dusun Sumberjo khususnya tidak mau memahami dengan permasalahan dusun yang ada. Sedangkan permasalahnan yang ada di Dusun Sumberjo sendiri adalah masalah yang klasik dan pelik.

Pengabdian kepada masyarakat (PkM) ini mengambil wilayah Dusun Sumberjo sebagai tempat terlaksananya progam karena didusun tersebut memiliki permasalahan yang sulit untuk di pecahkan. Oleh karena itu, atas saran dari warga, Pengabdian kepada masyarakat (PkM) mengambil wilayah di Dusun Sumberjo untuk membantu mengurangi permasalahan yang terjadi di dusun tersebut.

Ada beberapa permasalahan-permasalahan yang ada di Dusun Sumberjo Desa Wringinagung yang meliputi:

\section{Terdapat TPA (Tempat Pembuangan Akhir)}

Dusun Sumberjo yang masuk dalam Desa Wringinagung berbatasan langsung dengan Desa Tegalsari disebelah utara ini mempunyai TPA yang menampung sampah pasar dari tiga wilayah yaitu Srono, Cluring, dan Jajag, sampah yang berada di TPA sudah menggungung dan mengganggu kenyamanan warga sekitar, ketika musim hujan bau yang menyengat kerap kali menyebar dan menggangngu bahkan keluhan datang dari desa tetangga yang wilayahnya berbatasan dengan Dusun Sumberjo.

2. Tidak adanya kesadaran dan pemahaman mengenai pengolahan sampah.

Tanah yang ditempati oleh TPA adalah setengah milik warga dan 
setengah milik pemerintah, sering terjadi sengketa atas pembebasan lahan TPA, banyak warga yang meminta untuk TPA tersebut dipindah namun karena tanah tersebut setengah dari pemerintah maka sulit warga untuk mengatasinya, dan juga masyarakat Dusun Sumberjo yang kurang faham akan pengolahan sampah yang mana hingga sekarang tidak adanya penanganan khusus mengenai sampah di TPA.

Dusun Sumberjo Desa Wringinagung memiliki permasalahan yang cukup pelik mengenai sampah, penangananyapun tidak dapat instan perlu kesadaran dari warga sekitar untuk pemanfaatan dan juga pengolahan sampah. Dalam tahapan utama adalah perlunya sosialisai pemahaman sampah rumah tangga karena pemahaman lebih efektif dimulai dari lingkup keluarga, diharapakan kedepannya masyarakat Dusun Sumberjo Desa Wringinagung dapat memahami dan mengaplikasikan program pengolahan sampah non-organik tesebut.

Karena kurangnya pemahaman masyarakat akan pengolahan sampah maka program kerja "Sosialisasi Pemahaman tentang Pengolahan Sampah Rumah Tangga" dapat memberikan pemahaman baik dan membuka pikiran masyarakat dalam memahami permasalahan sampah.

\section{Metode}

Pendekatan yang digunakan dalam pemberdayaan kepada masyarakat ini adalah Participatory Action Research (PAR). Berbagai permasalahan yang belum terurai tersebut perlu usaha penggalian dan pendalaman sampai pada akar permasalahannya. Dalam hal ini akan dipaparkan secara mendalam beberapa aksi yang telah dilakukan oleh tim pendamping sebagai langkah awal untuk menggali dan menguraikan beberapa permasalahan yang ada di Dusun Sumberejo Desa Wringinagung Adapun pohon masalah yang ada di 
Dusun Sumberjo adalah sebagai berikut :

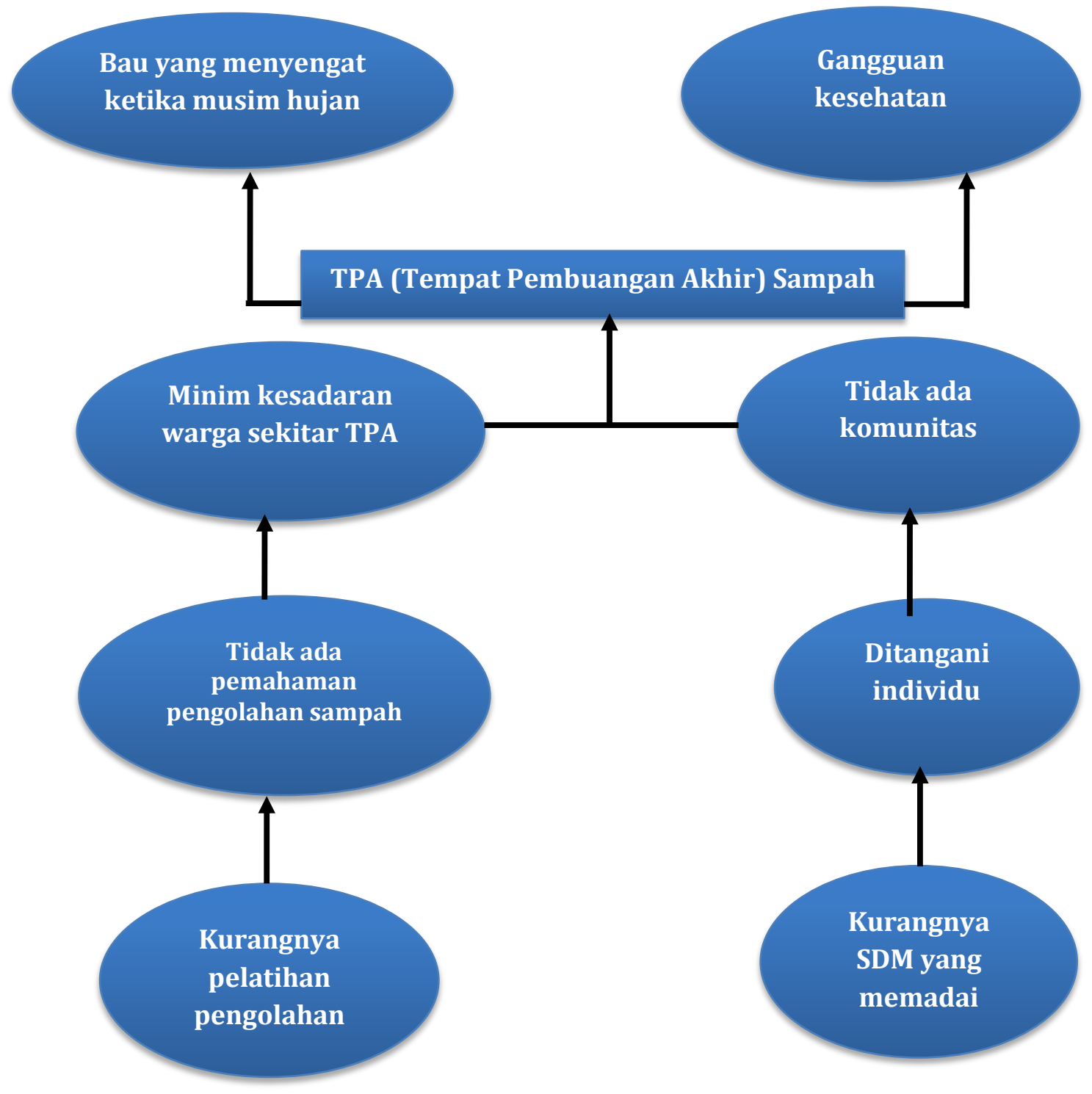

Gambar 1. Pohon Masalah Permasalan Sampah di Dusun Sumberjo (Sumber: Dokumentasi, 2018 (diolah))

Dari kerangka masalah terkait permasalahan sampah yang ada di Dusun Sumberjo tersebut maka tim pendampingan memunculkan beberapa harapan yang diharapkan dapat membantu terealisasinya beberapa program

Pemberdayaan Masyarakat Sekitar TPA (Tempat Pembuangan Akhir) Dalam Pemanfaatan Sampah Non Organik Menjadi Kerajinan Untuk Meningkatkan Nilai Jual

Moh. Mahmud, Sugiyono, Sumari Mawardi, Munawir 
kerja yang telah ditentukan. Adapun kerangka harapan sebagai berikut :

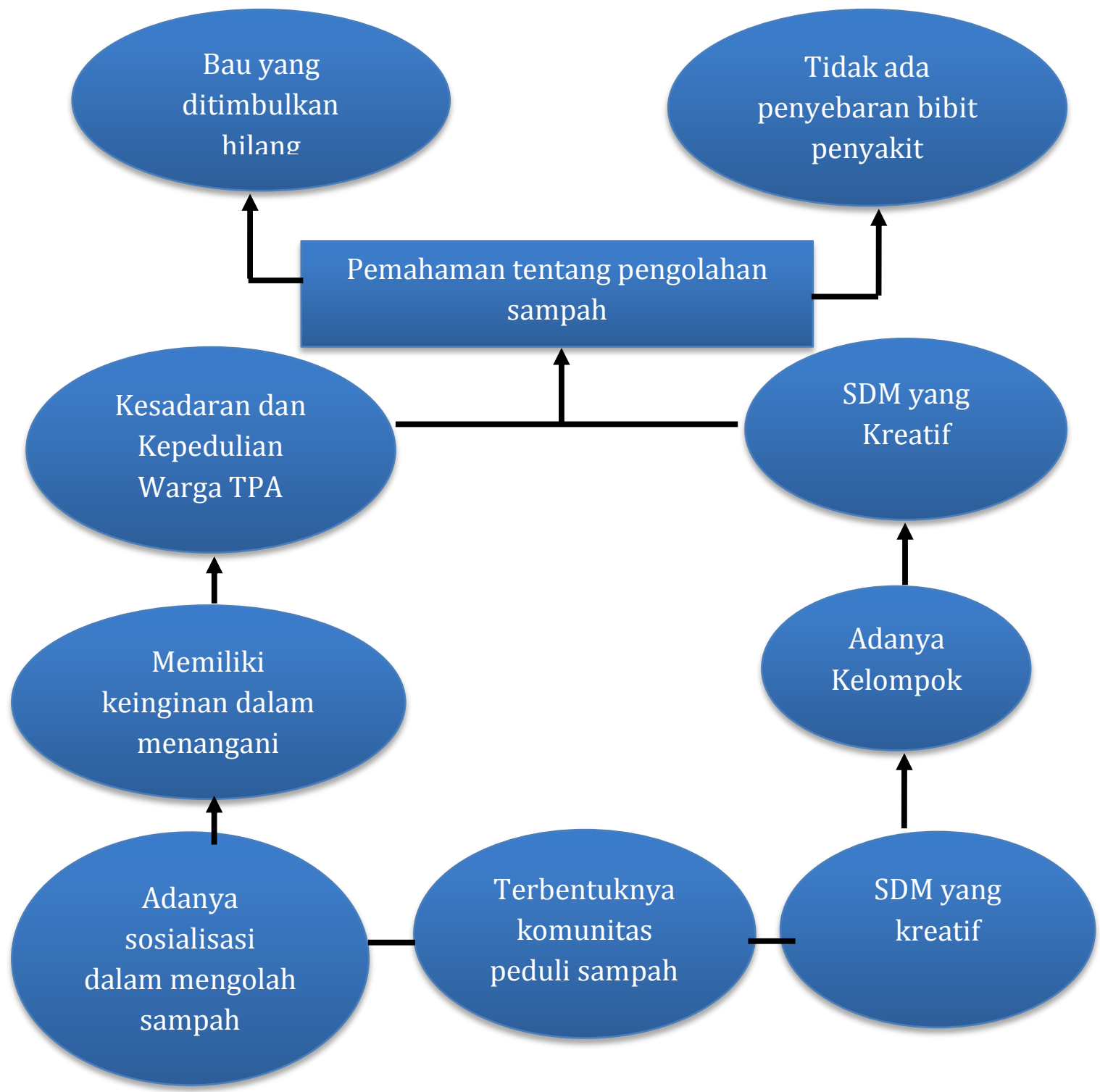

Gambar 2. Pohon harapan Dusun Sumberjo(Sumber: Dokumentasi, 2018 (diolah))

Diskusi dalam hal pemetaan masalah dan harapan ini difasilitasi oleh tim pendamping yang selanjutnya dari hasil diskusi dengan masyarakat tersebut dapat ditemukan bahwa permasalahan utama yang sejak dulu menghantui 
masyarakat Dusun Sumberjo tersebut adalah proses pengolahan sampah non-organik tersebut menjadi hasil kerjina tangan dalam rangka meningkatnkan nilai jual dan taraf ekonomi masyarakat.

\section{Hasil dan Diskusi}

Pelaksanaan Pengabdian kepada masyarakat (PkM) ini bertempat di desa Wringinagung yang terdiri dari 4 dusun yaitu dusun sumberjo.sumberjaya, jatisari, dan glowong. Para anggota tim pendamping melakukan observasi di 3 dusun yaitu Sumberjo, Sumberjaya, dan Glowong.

Di Dusun Glowong para anggota tim pendamping tidak menemukan masalah yang signifikan sehingga mereka melanjutkan observasi di Dusun Sumberjaya. Begitu juga di dusun ini tidak ada permasalahan yang pelik untuk di tangani para anggota tim pendamping. Yang terahir anggota tim pendamping melakukan observasi di Dusun Sumberjo dan anggota tim pendamping menemukan masalah yang serius yaitu adanya TPA (Tempat Pembuangan Akhir sampah) sehingga anggota tim pendamping melakukan observasi yang lebih mendalam mengenai TPA ini sehingga pada akhirnya memutuskan untuk mengambil permasalahan yang ada di sumberjo ini yaitu masalah penanganan sampah.

Pak samirin selaku petugas dari TPA yang berada di Dusun Sumberjo Desa Wringinagung Kecamatan Gambiran mengatakan bahwa penanganan sampah ini tidak ada bukti nyata yang dapat memecahkan permasalah di TPA Sumberjo yang mana apabila saat musim hujan akan timbul bau yang tak sedap dari TPA yang menyebar ke pemukiman warga dan jika sedang musim kering pak samirin akan membakar sampah tersebut dan menimbulkan asap yang tentunya mengangu kesehatan warga sekitar TPA, asal sampah yang ditimbun di TPA tersebut berasal dari tiga wilayah yaitu Jajag, Srono, dan Cluring, mengenai cara mengelola sampah pak samirin selaku petugas TPA 
pernah diadakanya pelatihan pembuatan pupuk kompos dari pihak pemerintah Banyuwangi, namun karena kendala penjualan dan juga tidak adanya pasar maka pak samirin enggan untuk meneruskan pengolahan pupuk kompos tersebut. Dan kurangnya kesadaran masyarakat sekitar untuk membantu dalam pengolaan pupuk kompos tersebut.

Setelah tim pendampingan melakukan observasi kepada warga sekitar TPA, banyak ditemukan keluhan-keluhan yang telah di alami warga, sepeti halnya bau sampah yang sangat menyengat terutama pada saat hujan dan menyebabkan adanya lalat yang berterbangan kesana kemari, jalanan rusak karena sering dilewati oleh truk-truk pengangkut sampah.Oleh karena itu harapan warga sekitar masyarakat yang tinggal di daerah sekitar TPA khususnya warga Rt 03/01 menginginkan adanya perbaikan dan penanganan khusus terhadap TPA tersebut agar para warga tersebut tidak merasa terganggu dengan adanya TPA yang berada disekitar pemukiman warga. Selain itu warga juga selalu menuntut kepada pemerintah desa supaya selalu melakukan pembenahan pada jalan yang sering di lewati oleh truk pengangkut sampah.

Setelah anggota tim melaksanakan observasi, ada beberapa program yang menjadi skala prioritas untuk dilaksanakan. Program tersebut direncanakan bersama sebagian komunitas masyarakat sebagai suatu solusi dari permasalahan yang ada. Adapun program tersebut adalah sebagai berikut :

\section{Mengadakan Sosialisasi Pemahaman Pengolahan Sampah Rumah} Tangga

Sampah merupakan sisa benda atau barang manusia yang telah digunakan dan merupakan konsekuensi dari adanya aktivitas manusia. Kehidupan manusia tidak pernah lepas dari masalah sampah, fakta 
menunjukkan bahwa potensi sampah terus meningkat seiring dengan pertambahan jumlah penduduk. Pada umumnya, sebagian besar sampah yang dihasilkan di tempat pembuangan akhir (TPA) merupakan sampah organik yang mudah terurai dan sampah anorganik. Sampah organik adalah sampah yang terbentuk dari zat-zat organik dan dapat diuraikan. Contoh sampah ini adalah daun sisa sayuran dll. Sedangkan sampah Anorganik adalah sampah yang berasal dari benda-benda yang tidak dapat diuraikan. Contohnya: Plastik, Kaleng, dan lain-lain.

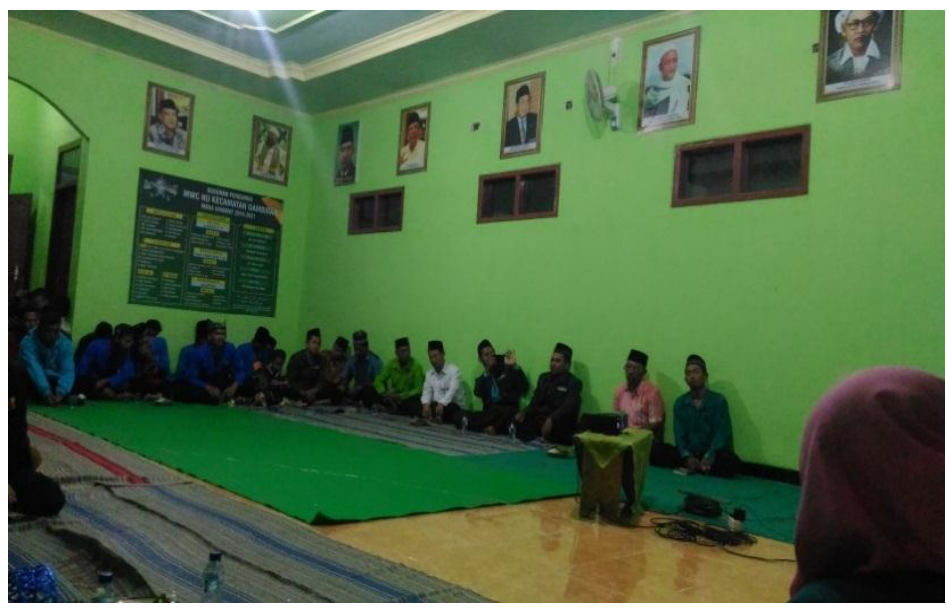

\section{Gambar 3. Sosialisasi Pemahaman Pengolahan Sampah Rumah Tangga} (Sumber: Dokumentasi Pengabdian, 2018 (diolah))

Masalah sampah saat ini termasuk sepele. Tetapi, jika kita sadari bahwa setiap orang mengeluarkan sampah dan akhirnya sampah tersebut akan menggunung. Untuk menanggulangi masalah sampah yang semakin banyak, orang-orang mulai memikirkan banyak cara. Mulai dari memisahkan sampah organik dan anorganik lalu menjadikan sebagai pupuk, tas, dll.

Sampah bisa diolah dengan berbagai cara salah satunya dengan menerapkan prinsip 3R. Metode ini bisa dilakukan dengan cara memilah 
sampah organik dan anorganik yaitu dengan cara membuat tempat sampah khusus untuk sampah organik dan anorganik. Dengan memilah sampah organik dan anorganik kita bisa mengolah sampah-sampah tersebut menjadi sesuatu yang bermanfaat.

Apa itu 3R? - Reduce berarti mengurangi sampah dengan mengurangi pemakaian barang atau benda yang tidak terlalu kita butuhkan. Reuse sendiri berarti memanfaatkan kembali barang yang sudah tidak terpakai. Recycle adalah mendaur ulang barang. Kita bias mendaur ulang sampah organic dan anorganik menjadi sesuatu yang bisa bermanfaat.

Selama ini sebagian besar masyarakat masih memandang sampah sebagai barang sisa yang tidak berguna, bukan sebagai sumberdaya yang perlu dimanfaatkan. Paradigma baru memandang sampah sebagai sumber daya yang mempunyai nilai ekonomi dan dapat dimanfaatkan, misalnya untuk energi, kompos, pupuk ataupun untuk bahan baku industri. Pengelolaan sampah dengan paradigma baru tersebut dilakukan dengan kegiatan pengurangan dan penanganan sampah. Masyarakat awam biasanya berpikir bahwa sampah rumah tangga yang di hasilkan tidak akan bermanfaat bagi mereka. Sampah yang di hasilkan tadi di biarkan menuju TPA (Tempat Pembuangan Akhir) tanpa menyadari bahwa sampah tersebut bisa sangat berguna bagi pendapatan mereka. Maka dari itu Dosen Pengabdian kepada Masyarakat ( $\mathrm{PkM}$ ) mengambil salah satu dari metode 3R tersebut yaitu berupa Recycle yang berrati mendaur ulang barang dengan harapan semoga dapat menambah penghasilan warga masyarakat sekitar.

\section{Pelatihan membuat kerajinan tangan}

Pelatihan (training) merupakan proses pembelajaran yang melibatkan perolehan keahlian, konsep, peraturan, atau sikap untuk meningkatkan kinerja tenga kerja.. Pelatihan kerja adalah keseluruhan kegiatan untuk 
memberi, memperoleh, meningkatkan, serta mengembangkan kompetensi kerja, produktivitas, disiplin, sikap, dan etos kerja pada tingkat ketrampilan dan keahlian tertentu sesuai dengan jenjang dan kualifikasi jabatan dan pekerjaan.

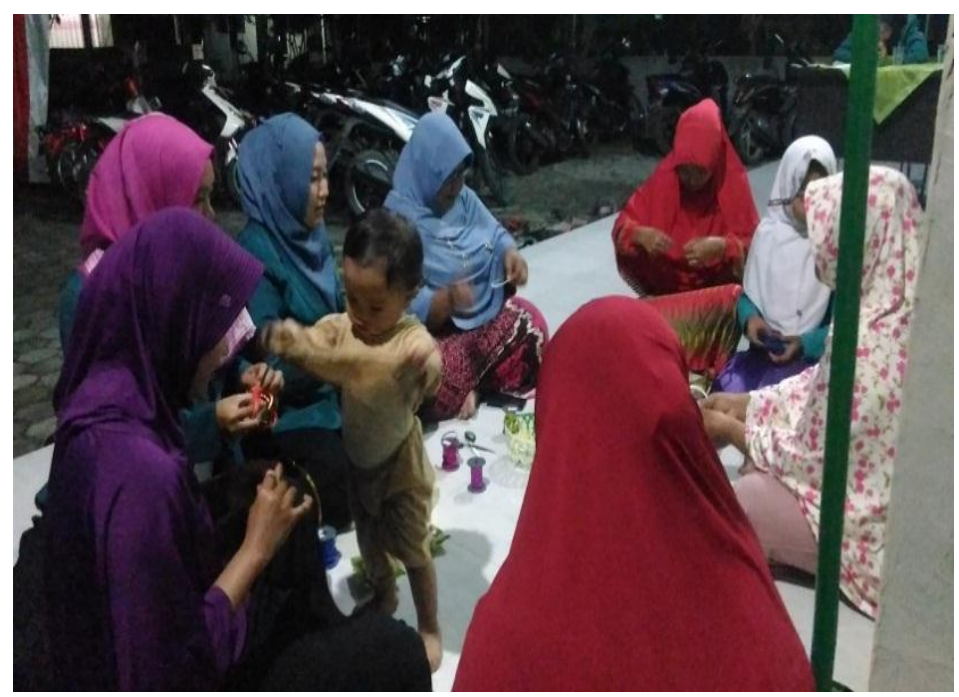

\section{Gambar 4. Pelatihan membuat Kerajinan Tangan Dari Bahan Sampah} (Sumber: Dokumentasi Pengabdian, 2018 (diolah))

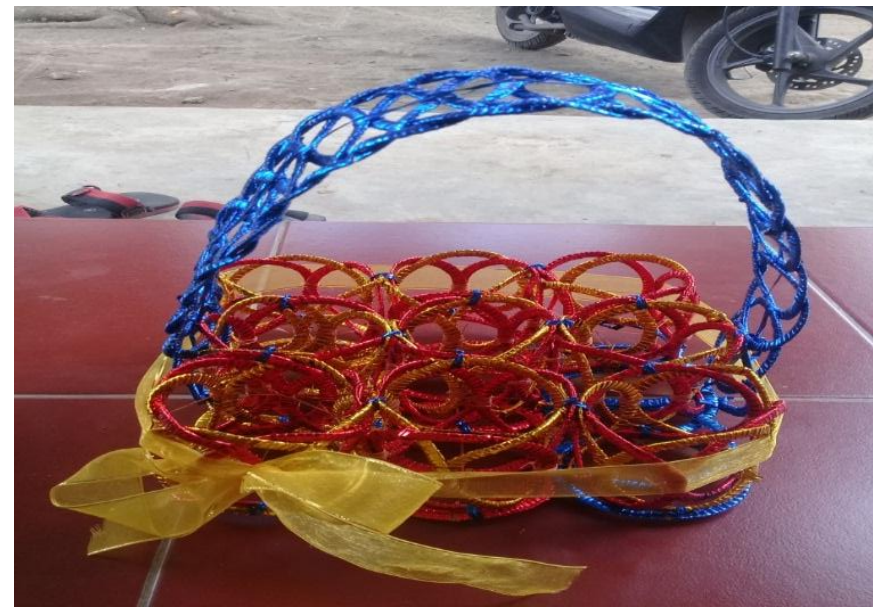

Gambar 5. Hasil Kerajinan Tangan Dari Bahan Sampah Non-Organik Sumber: Dokumentasi Pengabdian, 2018 (diolah))

Pemberdayaan Masyarakat Sekitar TPA (Tempat Pembuangan Akhir) Dalam Pemanfaatan Sampah Non Organik Menjadi Kerajinan Untuk Meningkatkan Nilai Jual

Moh. Mahmud, Sugiyono, Sumari Mawardi, Munawir 
Maka dari itu untuk menumbuhkan keterampilan yang dimiliki warga Dusun Sumberjo serta untuk memperluas khasanah keilmuan / pengetahuan khususnya ibu-ibu warga sekitar. Sesuai dengan program dari tim pendamping yang berhubungan dengan sampah tim pendamping memberikan pembelajaran tentang pembuatan kerajinan tangan dari bahan bekas botol minuman seperti membuat piring, mangkok dan wadah untuk menaruh minuman aqua.

Harapan besar dari diadakannya program ini adalah supaya bisa mewadahi para ibu-ibu dalam memaksimalkan waktunya guna mendapatkan incoma tambahan. Dalam pelaksanaannya khalayak sasaran kegiatan tersebut adalah masyarakat dusun Sumberjo desa Wringinagung. Melalui beberapa program kerja diharapkan masyarakat mampu bekerja sama untuk mengolah potensi daerah dan juga SDM yang dimiliki untuk meningkatkan kualitas hidup menjadi lebih baik. Oleh karena itu, tim pendamping berharap melalui program-program ini, masyarakat dusun Sumberjo melakukan beberapa program yang tujuannya dapat mengisi waktu senggang mereka untuk melakukan aktivitas pelatihan serta menjalankan Adapun lebih jelasnya proses pendampingan dapat di lihat pada tabel di bawah ini:

Tabel 1. Jadwal Pelaksanaan Pendampingan Kepada Masyarakat

\begin{tabular}{|c|l|c|}
\hline NO & \multicolumn{1}{|c|}{ Pelaksanaan } & Tanggal Dan Waktu \\
\hline 1 & Survey keadaan TPA & 5 Mei 2018 pukul 13:00 \\
\hline 2 & $\begin{array}{l}\text { Mendatangi Dinas Lingkungan Hidup (DLH) } \\
\text { Banyuwangi }\end{array}$ & 10 Mei 2018 pukul 10:00 \\
\hline 3 & Mendatangi Kades untuk membahas program PAR & 14 Mei 2018 pukul 14:15 \\
\hline 4 & $\begin{array}{l}\text { Menyebar undangan untuk kegiatan pengabdian } \\
\text { kepada masyarakat (PKM) }\end{array}$ & 25 Mei 2018 pukul 09:00 \\
\hline 5 & Sosialisasi Pemahaman sampah rumah tangga & 27 Mei 2018 pukul 19:00 \\
\hline 6 & Pembuatan kerajinan dari sampah non-organik & 27 Mei 2018 pukul 20:00 \\
\hline
\end{tabular}

(Sumber: Dokumentasi Pengabdian, 2018 (diolah))

Dengan bantuan dari masyarakat, Dinas Lingkungan Hidup dan 
terutama anggota Mars karangtaruna Dusun Sumberjo, kegiatan pengabdian kepada masyarakat (PKM) ini akan terus berlanjut berjalan meskipun para pendampingan sudah tidak lagi berkiprah di Desa Wringinagung. Semoga dengan di adakannya Sosialisasi Pemahaman Pengolahan Sampah Rumah Tangga, perangkat desa dan masyarakat dapat menyadari serta dapat menjadikan Desa Wringinagung khususnya Dusun sumberjo menjadi lebih baik.

\section{Simpulan}

Dari serangkaian program pemberdayaan masyarakat sekitar TPA di Dusun Sumberejo dalam pengolaahan sampah non-organik dapat terserap dengan maksimal sehingga masyarakat mampu mengelola sampah non organik dengan baik dengan didukung oleh keadaandan kondisi yang memadai dalam mengelola sampah non organik, sehingga dapat diprediksi di tahun yang akan datang bahwa Dusun Sumberjo Desa Wringinagung mampu menjadi Desa yang memiliki industri kerajinan tangan yang baik sehingga dapat meningkatkan tarap ekonomi masyarakat.

\section{Daftar Referensi}

Ardiansyah, Tomi. 2017. Sampah Anorganik Dan Pemanfaatannya. https://foresteract.com/sampah-anorganik-danpemanfaatannya/diakses: 15 Nopember 2019

BPPKKN PAR. Buku panduan KKN PAR 2018. Banyuwangi: LPPM IAIDA Blokagung Banyuwangi (2018).

Pemerintah Desa Wringinagung. 2018. Buku Profil Desa Wringinagung Tahun 2017. Desa Wringinagung Kecamatan Gambiran Kabupaten Banyuwangi. 